\title{
Rozwój rynku kontraktów terminowych na Giełdzie Papierów Wartościowych w Warszawie
}

Na Giełdzie Papierów Wartościowych w Warszawie 16 stycznia 1998 roku rozpoczęły się notowania kontraktów terminowych futures na indeks giełdowy WIG20. Tym samym został uruchomiony nowy rynek obok rynku kasowego rynek terminowy. 6-letni okres istnienia może być podstawą do dokonania próby oceny.

Rozwój rynku terminowego można podzielić na dwa etapy. Pierwszy to lata 1998-1999, w których kontrakty dopiero się pojawiły i umocowały na naszej giełdzie. Drugi to lata 2000-2004, kiedy nastapił dynamiczny rozwój rynku kontraktów terminowych.

W pierwszym etapie rozpoczęto notowania kontraktów terminowych bezwarunkowych futures WIG20, futures USD, futures EURO, w drugim etapie futures TechWIG, futures na akcje oraz na MIDWIG. W całym omawianym okresie największe znaczenie odgrywał kontrakt futures WIG20 i stanowił on $98 \%$ globalnych obrotów na derywatach.

Na GPW w kontrakty inwestują trzy grupy inwestorów: inwestorzy zagraniczni, inwestorzy krajowi indywidualni i krajowi instytucjonalni. Struktura udziału poszczególnych grup inwestorów w porównaniu z rynkiem kasowym jest odmienna. Na rynku kasowym poszczególne grupy inwestorów mają zbliżony udział w rynku. Występuje również tendencja wzrostu udziału w rynku inwestorów instytucjonalnych. Na rynku terminowym dominują krajowi inwestorzy indywidualni, natomiast rolę marginalną pełnią zagraniczni inwestorzy. W 1999 roku udział inwestorów krajowych wynosił $96 \%$, a zagranicznych $4 \%$. W analizowanym okresie struktura ta uległa niewielkim zmianom. W 2003 roku zmniejszył się udział krajowych inwestorów indywidualnych do $75 \%$ i zagranicznych do $2 \%$. Zwiększyła się rola instytucjonalnych inwestorów krajowych. W 1999 roku stanowili oni $15 \%$ ogółu inwestorów, podczas gdy w 2003 roku $23 \%$. 
Tabela 1

Udzial grup inwestorów w obrotach akcjami i kontraktami terminowymi w latach 1999$-2003(w \%)$

\begin{tabular}{|l|c|c|c|c|c|}
\hline Inwestorzy & 1999 & 2000 & 2001 & 2002 & 2003 \\
\hline Zagraniczni & 34 & 28 & 34 & 36 & 35 \\
\hline Krajowi instytucjonalni & 22 & 22 & 29 & 33 & 37 \\
\hline Krajowi indywidualni & 44 & 50 & 37 & 31 & 28 \\
\hline
\end{tabular}

Źródło: Roczniki GPW.

Tabela 2

Udział grup inwestorów w obrotach kontraktami terminowymi w latach 1999-2003 (w \%)

\begin{tabular}{|l|c|c|c|c|c|}
\hline Inwestorzy & 1999 & 2000 & 2001 & 2002 & 2003 \\
\hline Zagraniczni & 4 & 2 & 2 & 2 & 2 \\
\hline Krajowi instytucjonalni & 15 & 13 & 15 & 19 & 23 \\
\hline Krajowi indywidualni & 81 & 85 & 83 & 79 & 75 \\
\hline
\end{tabular}

Źródło: Roczniki GPW.

Rynek kontraktów terminowych jest najszybciej rozwijającym się rynkiem GPW. W 1998 roku, roku debiutu, wartość obrotów kontaktami terminowymi stanowiła $1 \%$ obrotu rynku kasowego. W następnym roku relacja ta wynosiła $7 \%$. Porównując obroty kontraktami futures WIG20, które stanowiły $98 \%$ globalnych obrotów derywatami, z rynkiem kasowym od stycznia do sierpnia 2000 roku, stwierdzamy; iż relacje te kształtowały się na poziomie 5\%. Dopiero pod koniec sierpnia obroty kontraktami futures WIG20 wynosiły $17 \%$ obrotów rynku kasowego. W latach 2001-2002 wartość obrotów derywatami przekroczyła wartości obrotów na rynku kasowym (transakcje natychmiastowe) o 19\%. W 2003 roku nastapił dalszy dynamiczny rozwój kontraktów terminowych. W tymże roku obroty derywatów przekroczyły o $158 \%$ obroty na rynku kasowym akcji .

\section{Tabela 3}

Wartość obrotów na rynku kasowym i na rynku terminowym w latach 1998-2003 ( $w \mathrm{mln}$ zł)

\begin{tabular}{|l|c|c|c|c|c|c|}
\hline Wyszczególnienie & $\mathbf{1 9 9 8}$ & $\mathbf{1 9 9 9}$ & $\mathbf{2 0 0 0}$ & $\mathbf{2 0 0 1}$ & $\mathbf{2 0 0 2}$ & $\mathbf{2 0 0 3}$ \\
\hline Rynek kasowy & 62338 & $\mathbf{8 8 9 7 4}$ & 169096 & 80443 & 63662 & 79774 \\
\hline Rynek terminowy & 602 & 6368 & 58612 & 98646 & 77334 & 116201 \\
\hline
\end{tabular}

Źródło: obliczenia własne na podstawie Roczników GPW. 
W porównaniu $\mathrm{z}$ innymi terminowymi rynkami $\mathrm{w}$ krajach europejskich Giełda Papierów Wartościowych odgrywa coraz większą rolę. W 2003 roku nastapił 35-procentowy wzrost wolumenu obrotów kontraktami WIG20 w porównaniu z 2002 rokiem. Obroty kontraktem wynosiły 4,11 mln. Kontrakt ten pod względem wolumenu obrotu zajmuje 9. miejsce w Europie. W ciagu jednego roku wyprzedziliśmy giełdy w Hiszpanii i LIFE (aktualnie w ramach Euronextu). Większe obroty zanotowano na giełdach Eurex, Euronext (Amsterdam, Bruksela, Londyn, Lizbona, Paryż), Sztokholmie, Lizbonie.

Pod względem wartości obrotów na główne indeksy giełdowe giełda warszawska zajęła w 2003 roku, podobnie jak w 2002 roku, 7. miejsce w Europie, po Eurex, Euronext, Mediolanie, Hiszpanii, Sztokholmie, Atenach.

Pod względem 31-procentowego wzrostu wartości obrotu kontrakt na WIG20 zajmował w 2003 roku 3. miejsce w Europie, po kontrakcie BUX (wzrost o 34\%) i kontrakcie KFX (32\%).

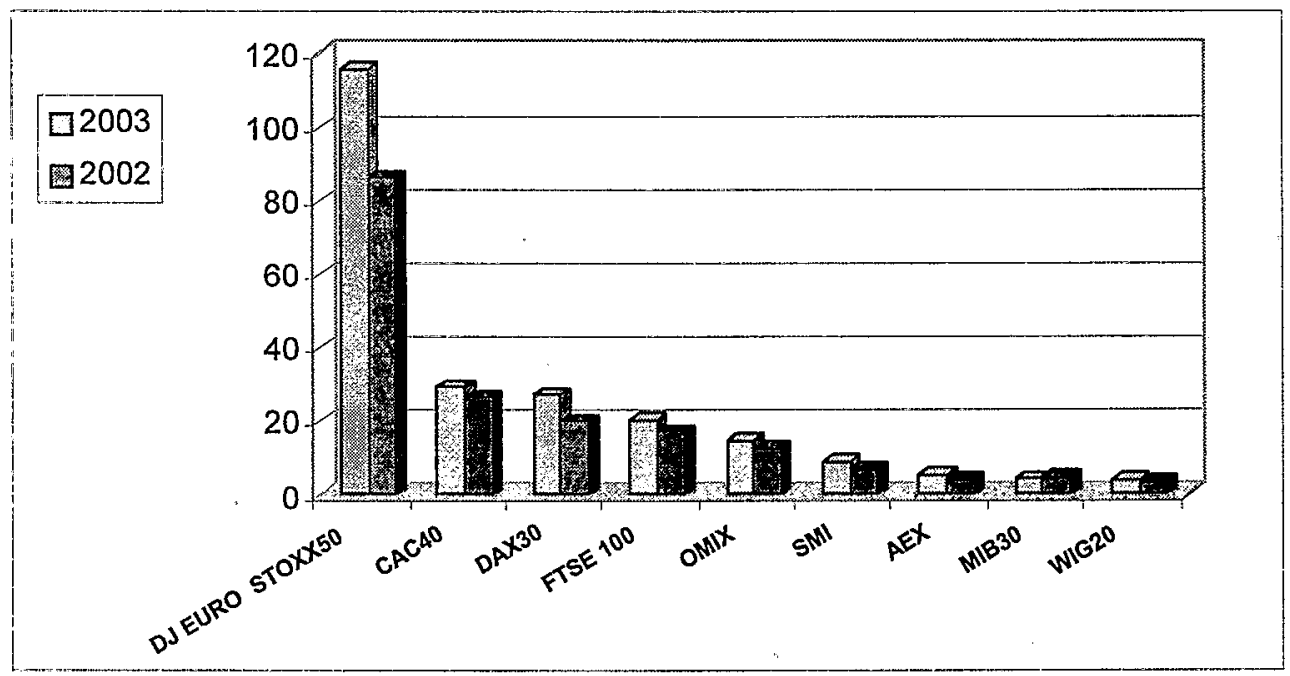

\section{Rysunek 1}

Wolumen obrotów kontraktami na główne indeksy giełdowe w mln Źródło: obliczenia własne na podstawie Roczników GPW.

Sukcesem giełdy był i jest dynamiczny rozwój kontraktów terminowych na indeks WIG20. Wolumen obrotu kontraktami WIG20 w 1999 roku był ponadośmiokrotnie wyższy niż w 1998 roku i wynosił 203843 dla WIG20. Na koniec 1999 roku transakcje mogły być zawierane przez 7 tysięcy inwestorów za pośrednictwem 23 podmiotów dopuszczonych do działania na tym rynku. W ostatnim kwartale 1999 roku wartość obrotu kontraktami stanowiła 20\% obrotu na rynku akcji w systemie notowań ciagłych. Rok 2000 to również rok 
udany dla kontraktów WIG20. Wolumen obrotów wzrósł również ośmiokrotnie i wynosił 1490 tys. sztuk, co daje średni dzienny wolumen 5960 kontraktów. Również znacząco wzrosła liczba otwartych pozycji, z 4845 w 1999 roku do $11116 \mathrm{w} 2000 \mathrm{roku}, \mathrm{tj}$. o 130\%. Poczatek 2001 roku był niezwykle interesującym okresem na rynku kasowym i terminowym, o wyjątkowo dużym zainteresowaniu rynkiem derywatów w porównaniu do poprzednich kwartałów. Średnie obroty na sesję wynosiły $384 \mathrm{mln} \mathrm{zt}$, co w porównaniu z 2000 rokiem daje wzrost o przeszło $30 \%$. Wolumen obrotów w 2002 roku był średnio o 1/3 większy niż w 2000 roku.

Dla zapewnienia płynności na rynku praw pochodnych niektórzy członkowie GPW pełnią funkcję animatorów rynku. Na koniec 2002 roku funkcję animatora pełniło 6 domów maklerskich, m.in.: BRE Banku, BIG-BG, BOŚ, PEKAO. Są one zobowiązani są oni na podstawie umowy zawartej z giełdą do umieszczania w arkuszu zleceń własnych zleceń kupna i sprzedaży. W porównaniu z latami 2000 i 2001 w 2003 roku liczba otwartych pozycji w kontraktach WIG20 wzrosła o 90\%. Średni obrót na sesję w ostatnim roku analizy, w porównaniu z 2000 rokiem również zwiększył się o $100 \%$. Wolumen obrotu wzrósł o 35\%, a wartość obrotu o 31\% w zestawieniu z 2002 rokiem. Od lipca do listopada 2003 roku znacznie zwiększył się wolumen obrotu kontraktem WIG20. W porównaniu $\mathrm{z}$ czerwcem obroty we wrześniu i październiku wzrosły o $160 \%$. Tak dynamiczny wzrost obrotów przyczynił się do zajęcia znaczącej pozycji na rynkach terminowych w Europie. Popularność kontraktów terminowych wśród inwestorów rosła $w$ tempie geometrycznym, osiągając we wrześniu 2003 roku - 559880 sztuk.

Przy wysokiej płynności kontrakty są instrumentem dostępnym, dzięki któremu, można dokonywać spekulacji na rynku zniżkującym, zarabiać na spadkach. Pozwalają one również na dokonywanie zabezpieczenia portfela, są również doskonałym instrumentem do dokonywania transakcji arbitrażowych.

W pierwszym okresie rozwoju kontraktów terminowych rozpoczęto notowania walutowymi kontraktami futures. W przypadku kontraktów walutowych nastapiła stagnacja na bardzo niskim poziomie. Nie powtórzył się fenomen kontraktów na WIG20. Wartość obrotu kontraktami na EURO zwiększyła się w latach 1999-2003 jedynie dwukrotnie, podczas gdy kontraktami na WIG20 blisko 190-krotnie. W całym 2003 roku liczba otwartych pozycji w przypadku kontraktów na kurs euro wynosiła 165 i była o połowę niższa niż w 1999 roku. Liczba transakcji na sesję zmniejszyła się trzykrotnie w porównaniu z pierwszym rokiem notowań i wynosiła 10 . 


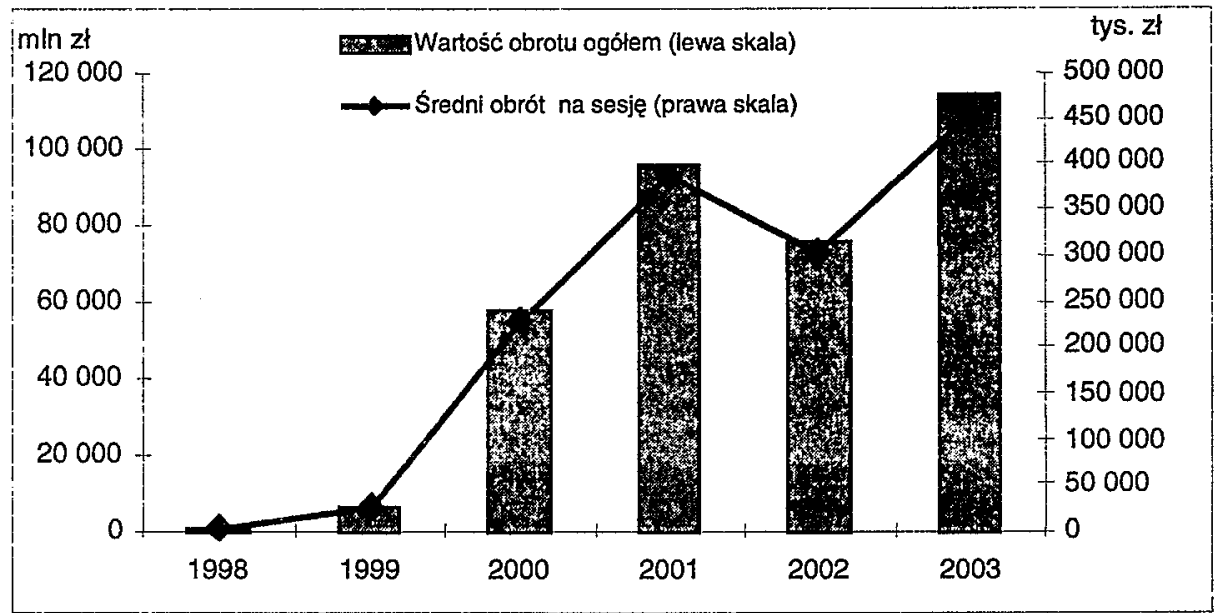

\section{Rysunek 2}

Kontrakty terminowe na WIG20 w latach 1998-2003; wartość obrotu ogółem (mln zł), średni obrót na sesję (tys. zł)

Źródło: obliczenia własne na podstawie Roczników GPW.

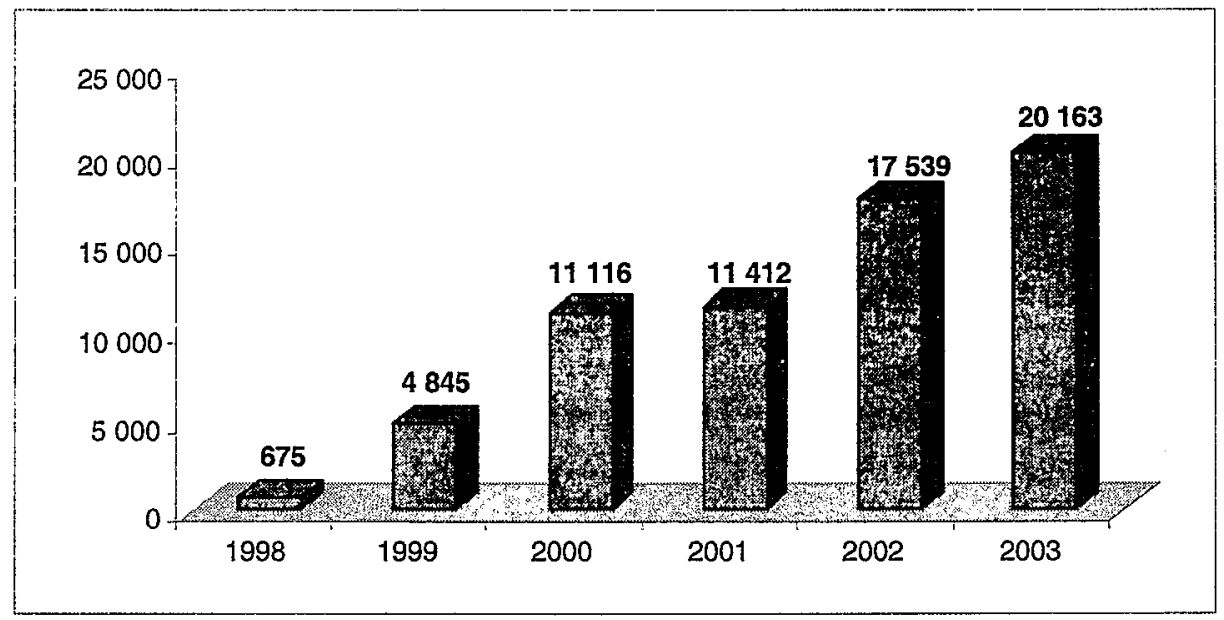

\section{Rysunek 3}

Kontrakty terminowe na WIG20 w latach 1998-2003; liczba otwartych pozycji (na koniec roku)

Źródło: obliczenia własne na.podstawie Roczników GPW 


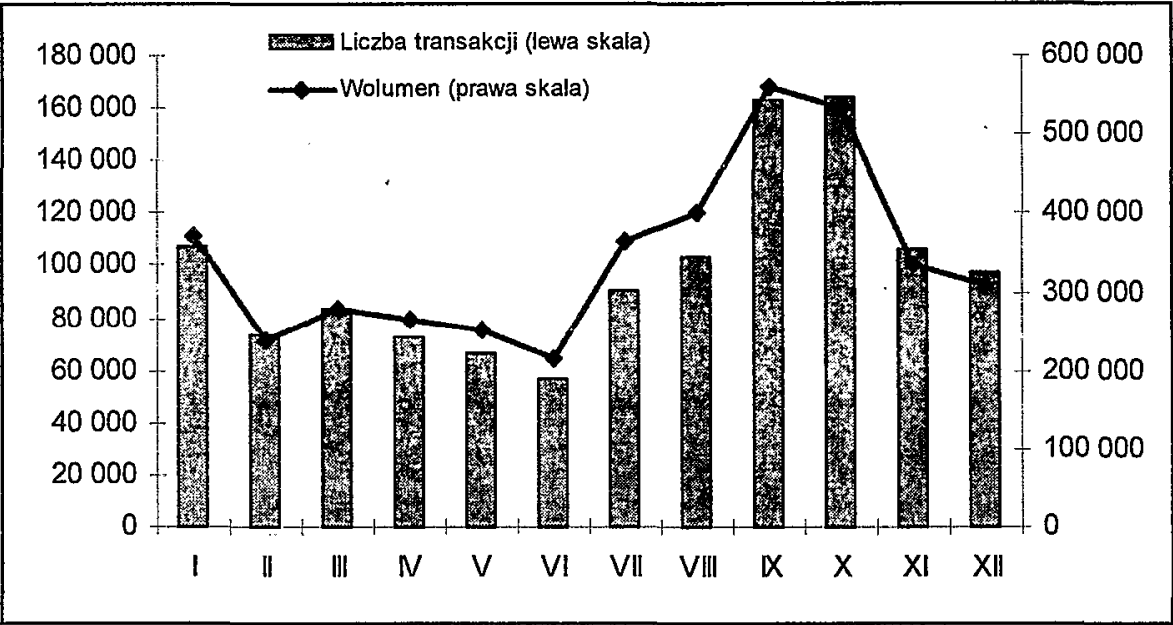

\section{Rysunek 4}

Kontrakty terminowe na WIG20 w kolejnych miesiącach 2003 r.; liczba transakcji, wolumen

Żródło: obliczenia własne na podstawie Roczników GPW.



\section{Rysunek 5}

Kontrakty terminowe na WIG20 w kolejnych miesiacach 2003 r.; liczba otwartych pozycji Źródło: obliczenia własne na podstawie Roczników GPW. 
Podobnie ksztaltowała się sytuacja dla kontraktów terminowych na USD. Wartość obrotów w tym okresie zmniejszyła się ze $186 \mathrm{mln}$ zł w 1999 roku do $166 \mathrm{mln}$ zł w 2003 roku. W 2003 roku liczba otwartych pozycji w przypadku kontraktów na kurs dolara wynosiła 85 i była o połowę niższa niż w 1999 roku. Liczba transakcji na sesje nieznacznie zmniejszyła się w porównaniu z 1999 rokiem i wynosiła w 2003 roku $661 \mathrm{mln}$ zl, podczas gdy w 1999 roku $744 \mathrm{mln}$ zł. Lata 1998-1999 dla notowań kontraktami dolarowymi był udane. Liczby charakteryzujące ten rynek wskazywały na jego dynamiczny rozwój. W następnych latach nastapiła stagnacja. Jest to spowodowane tym, iż głównym celem inwestorów uczestniczących na terminowych rynkach walutowych jest zabezpieczenie swoich transakcji. Większość inwestorów wycofała się z Giełdy Papierów Wartościowych. Inwestorzy dokonywali transakcji zabezpieczających na rynku międzybankowym. Na giełdzie pozostali przede wszystkim spekulanci.

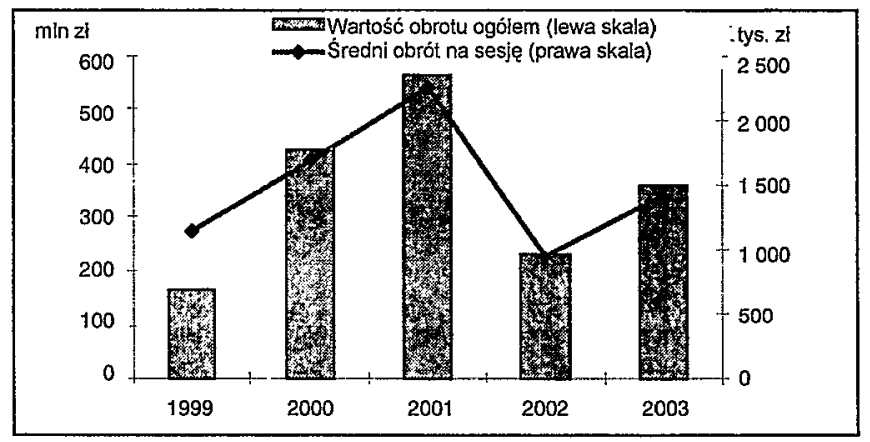

\section{Rysunek 6}

Kontrakty terminowe na EURO w latach 1999-2003; wartość obrotu ogólem, średni obrót na sesję (w 1999 r. 146 sesji)

Źródło: obliczenia własne na podstawie Roczników GPW.

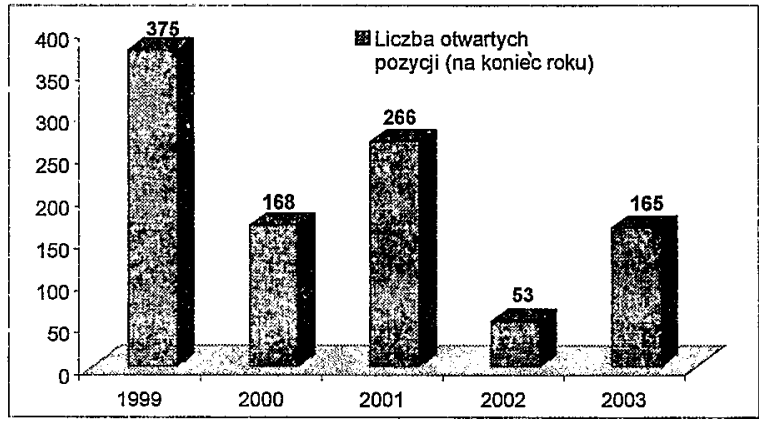

\section{Rysunek 7}

Kontrakty terminowe na EURO w latach 1999-2003; liczba otwartych pozycji (w 1999 r. 146 sesji)

Źródło: obliczenia własne na podstawie Roczników GPW. 




\section{Rysunek 8}

Kontrakty terminowe na USD w latach 1998-2003; wartość obrotu ogółem, średni obrót na sesję (w 1998 r. 67 sesji)

Źródło: obliczenia własne na podstawie Roczników GPW.

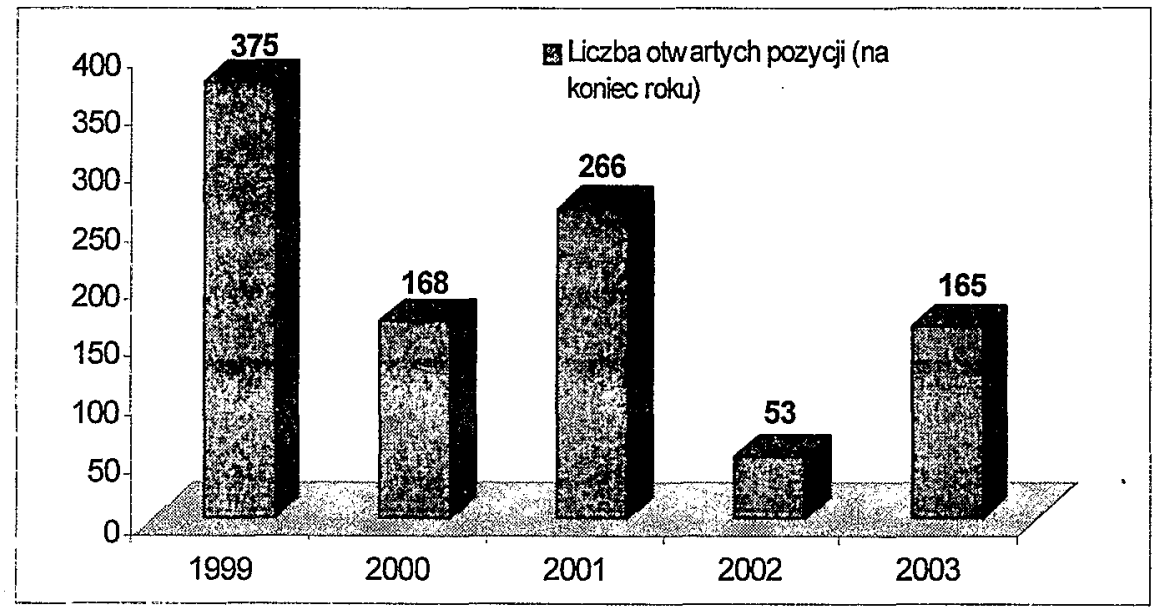

\section{Rysunek 9}

Kontrakty terminowe na EURO w latach 1999-2003; liczba otwartych pozycji Żródło: obliczenia własne na podstawie Roczników GPW. 


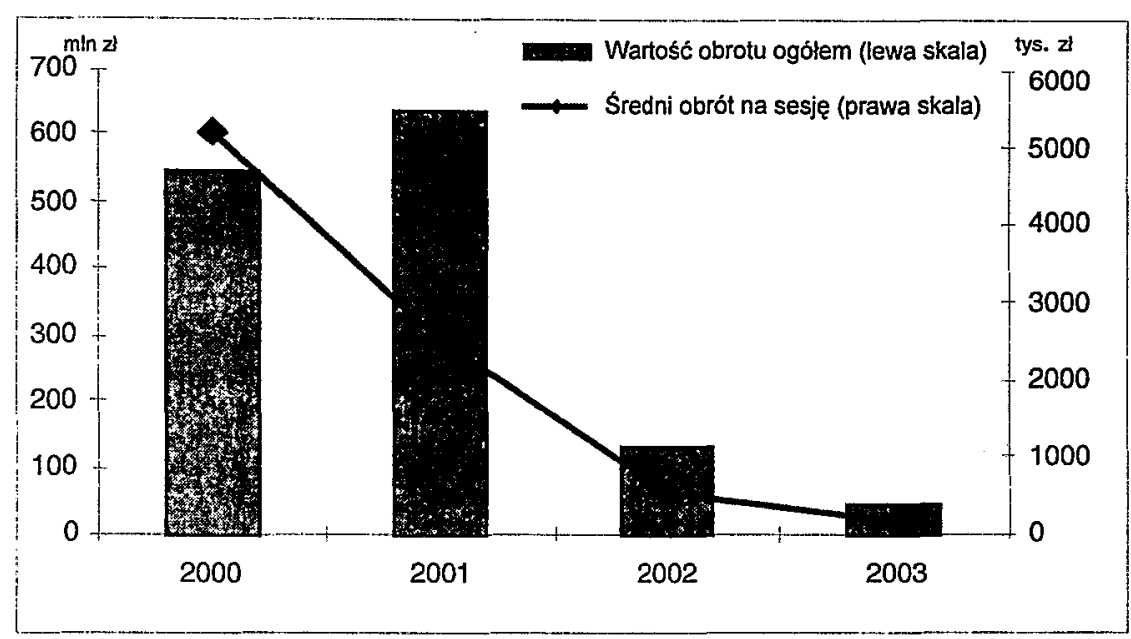

\section{Rysunek 10}

Kontrakty terminowe na TechWIG w latach 2000-2003 (w 2000 r. 105 sesji) Żródło: obliczenia wlasne na podstawie Roczników GPW.

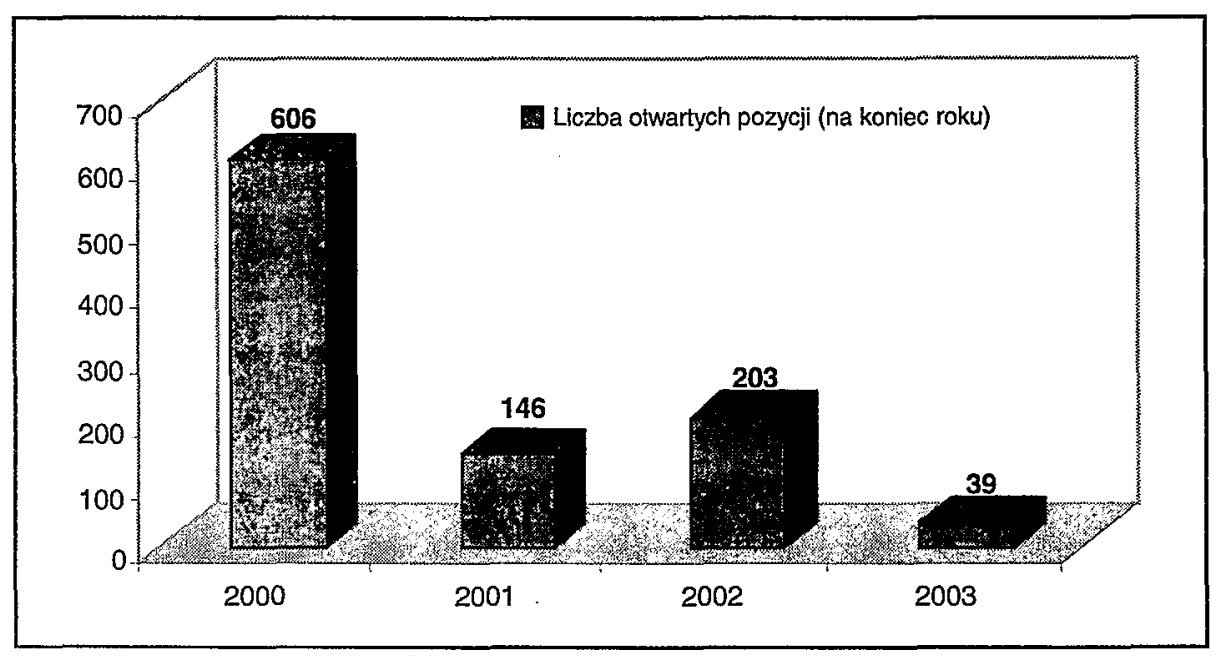

\section{Rysunek 11}

Kontrakty terminowe na TechWIG w latach 2000-2003; liczba otwartych pozycji (w 2000 r. 105 sesji)

Źródło: obliczenia własne na podstawie Roczników GPW. 
W drugim etapie rozwoju kontraktów terminowych wprowadzono trzy kontrakty terminowe: TechWIG, kontrakty na akcje i MIDWIG.

W połowie 2000 giełda wprowadziła do obrotu nowy indeks TechWIG, jednak, mimo atrakcyjności sektora technologicznego, nie odniósł on sukcesu. Średni obrót na sesję zmniejszył się z 5190 tys. zł w roku debiutu na giełdzie do 172 tys. zł w 2003 roku. Wartość obrotu w tym okresie zmniejszyła się dziesięciokrotnie, a liczba otwartych pozycji zmalała 15-krotnie, obniżył się również wskaźnik płynności. Małe zainteresowanie wynika w głównej mierze z dużej korelacji między indeksem WIG20 a indeksem TechWIG. W 2003 roku, pomimo czterech lat notowań rynkowych, TechWIG cieszył się coraz mniejszym zainteresowaniem.

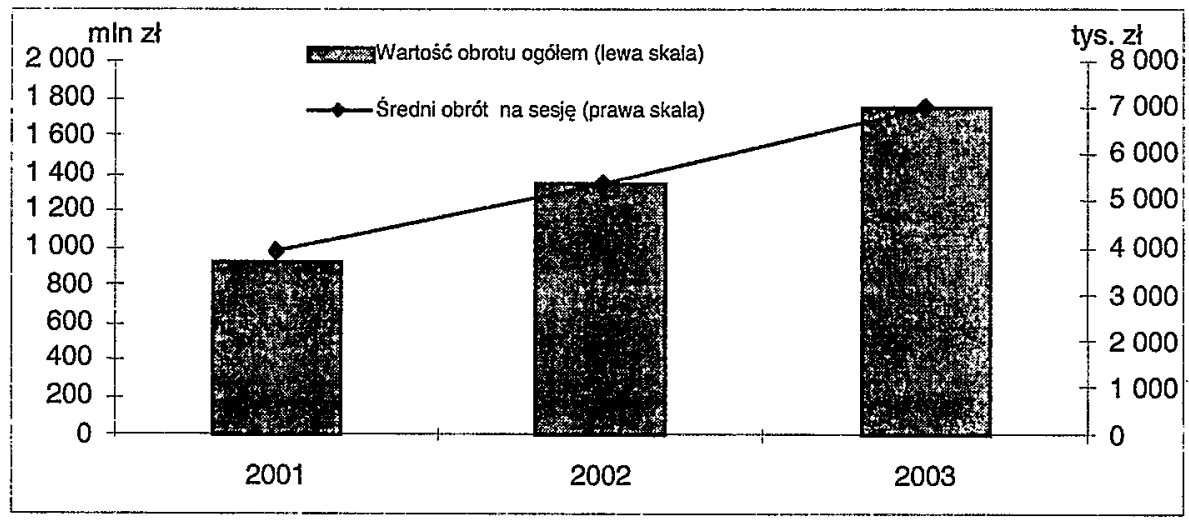

\section{Rysunek 12}

Kontrakty terminowe na akcje w latach 2001-2003 (w 2001 r. 236 sesji)

Źródło: obliczenia własne na podstawie Roczników GPW.

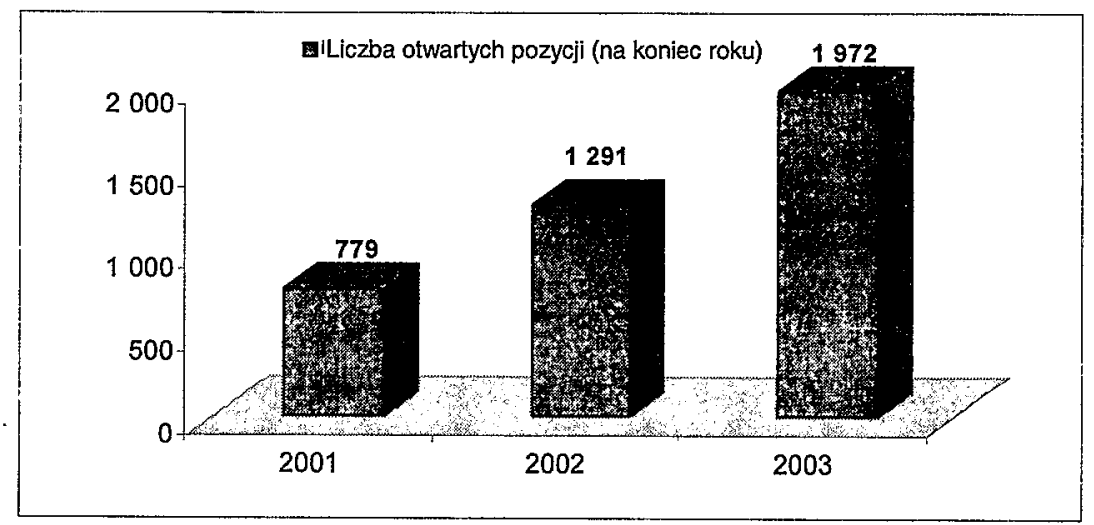

Rysunek 13

Kontrakty terminowe na akcje w latach 2001-2003; liczba otwartych pozycji (w $2001 \mathrm{r}$. 236 sesji)

Źródlo: obliczenia własne na podstawie Roczników GPW. 
Pozostałe dwa kontrakty odgrywają niewielką rolę na giełdzie, ale w porównaniu z powyższym kontraktem zwiększają swój udział w rynku.

W 2001 roku rozpoczęto notowania na giełdzie kontraktów na akcje. Kontrakty te służą inwestorom głównie do zabezpieczania pozycji na rynku kasowym. W tymże roku notowane były na 236 sesjach. Obrót tym kontraktem stanowił $1,5 \%$ globalnych obrotów kontraktami terminowymi, co stawia ten kontrakt na drugim miejscu po WIG20. Wskaźniki statystyczne charakteryzujące ten kontrakt podwoiły się. Średni obrót na sesje zwiększył się z 3909 tys. zł w roku debiutu na giełdzie do 7003 tys. zł w 2003 roku. Wartość obrotu w tym okresie zwiększyła się z $923 \mathrm{mln}$ zł do $1758 \mathrm{mln}$ zł, a liczba otwartych pozycji wzrosła z 779 w 2001 roku do 1972 w 2003 roku, podwyższył się również wskaźnik płynności.

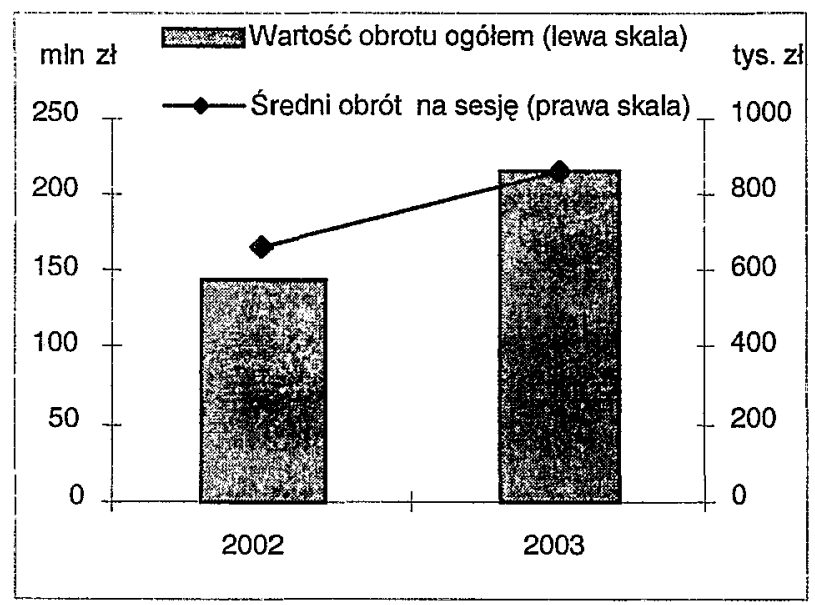

\section{Rysunek 14}

Kontrakty terminowe na MIDWIG (w 2002 r. 216 sesji)

Źródło: obliczenia własne na podstawie Roczników GPW.

Ostatni terminowy bezwarunkowy (musi być absolutnie rozliczony) kontakt terminowy notowany na naszej giełdzie to wprowadzony w 2002 roku (na 216 sesjach) kontrakt na MIDWIG. Średni obrót na sesję zwiększył się w 2003 roku w porównaniu z ubiegłym o $29 \%$, z 668 tys. zł w roku debiutu na giełdzie do 857 tys. zł. Wartość obrotu w tym okresie zwiększyła się o $49 \%$, ze $144 \mathrm{mln}$ zł do $215 \mathrm{mln}$ zł, a liczba otwartych pozycji zmalała o $10 \%$, podwyższył się natomiast wskaźnik płynności. 


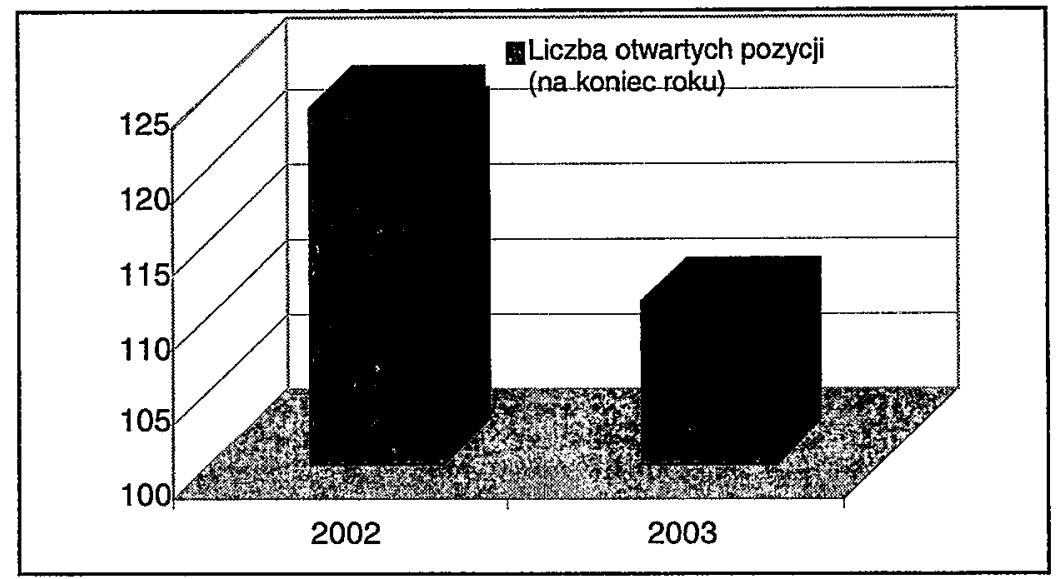

Rysunek 15

Kontrakty terminowe na MIDWIG w latach 2002-2003 (w 2002 r. 216 sesji)

Źródło: obliczenia własne na podstawie Roczników GPW.

\section{Podsumowanie}

Po sześciu latach istnienia rynku kontraktów terminowych tak naprawdę poważne znaczenie ma jedynie kontrakt futures na indeks giełdowy WIG20. Stale wzrastająca średnia liczba kontraktów zawieranych na każdej sesji zwiększa możliwości zmiany wcześniej zajętej pozycji oraz możliwość precyzyjniejszej wyceny instrumentu, o czym świadczy wskaźnik płynności, który zwiększył się z 2,2 w 1998 roku do 68,6 w 2000 roku i 207 w 2003 roku.

Rynek kontraktów terminowych jest najszybciej rozwijającym się rynkiem GPW. W 1998 roku, roku debiutu, wartość obrotów kontaktami terminowymi stanowiła $1 \%$ obrotu rynku kasowego. W następnym roku relacja ta wynosiła $7 \%$. Pod koniec sierpnia 2000 roku obroty kontraktami futures WIG20 wynosiły 17\% obrotów rynku kasowego. W latach 2001-2002 wartość obrotów derywatami stanowiła 119\% wartości obrotów na rynku kasowym. W 2003 roku nastapił dalszy dynamiczny rozwój kontraktów terminowych. W tymże roku obroty kontraktami futures stanowiły $158 \%$ obrotów rynku kasowego akcji.

\section{Literatura}

HULL J., 1997: Kontrakty terminowe i opcje - wprowadzenie. WIG Press, Warszawa. Roczniki giełdowe 2000, 2001, 2002, 2002, GPW.

ZALEWSKI G., 2000: Kontrakty terminowe w praktyce. WIG Press, Warszawa. 


\title{
The Development of Future Contracts Market at the Warsaw Stock Exchange in Warsaw
}

\begin{abstract}
The development of future contracts market can be divided into two stages. The first stage includes the period 1998-1999, when future contracts appeared and strengthen its position at the Warsaw Stock Exchange. The second stage includes the period 2000-2004, when a dynamic development of future contracts occurred. In the first stage quotations of unconditional future contracts futures WIG20, futures USD, futures EURO were started, while in the second stage: futures TechWIG, futures on shares and futures on MIDWIG. In the analyzed period the contract futures WIG20 was of great importance with the share of $98 \%$ in total turnovers on derivatives.

The future contracts market is the fastest developing market on the Warsaw Stock Exchange. In 1998, the year of the debut, the value of turnovers of future contracts amounted to $1 \%$ of spot market turnovers. In the next year this relationship amounted to $7 \%$. In the end of 2000 turnovers of future contracts amounted to $17 \%$ of spot market turnovers. In the years 2001-2002 the value of turnovers of derivatives amounted to $119 \%$ of the value of spot market turnovers. In 2003 the dynamic development of future contracts was continued. Turnovers of future contracts amounted to $158 \%$ of spot market turnovers.
\end{abstract}

